\title{
The Alzheimer's disease risk factors apolipoprotein E and TREM2 are linked in a receptor signaling pathway
}

\author{
Charlotte Jendresen ${ }^{1}$, Vibeke Årskog ${ }^{1}$, Michael R. Daws ${ }^{2}$ and Lars N. G. Nilsson ${ }^{1 *}$ (I)
}

\begin{abstract}
Background: Triggering receptor expressed on myeloid cells 2 (TREM2) and apolipoprotein E (APOE) are genetically linked to Alzheimer's disease. Here, we investigated whether human ApoE mediates signal transduction through human and murine TREM2 and sought to identify a TREM2-binding domain in human ApoE.

Methods: To investigate cell signaling through TREM2, a cell line was used which expressed an NFAT-inducible $\beta$-galactosidase reporter and human or murine TREM2, fused to CD8 transmembrane and CD3 intracellular signaling domains. ELISA-based binding assays were used to determine binding affinities of human ApoE isoforms to human TREM2 and to identify a TREM2-binding domain in ApoE.

Results: ApoE was found to be an agonist to human TREM2 with $\mathrm{EC}_{50}$ in the low $\mathrm{nM}$ range, and to murine TREM2 with reduced potency. In the reporter cells, TREM2 expression was lower than in nontransgenic mouse brain. Human ApoE isoforms $\varepsilon 2, \varepsilon 3$, and $\varepsilon 4$ bound to human TREM2 with $K_{d}$ in the low nM range. The binding was displaced by an ApoE-mimetic peptide (amino acids 130-149).

Conclusions: An ApoE-mediated dose-dependent signal transduction through TREM2 in reporter cells was demonstrated, and a TREM2-binding region in ApoE was identified. The relevance of an ApoE-TREM2 receptor signaling pathway to Alzheimer's disease is discussed.
\end{abstract}

Keywords: Alzheimer's disease, Apolipoprotein E (ApoE), Triggering receptor expressed on myeloid cells 2 (TREM2), Reporter cells, Neuroinflammation

\section{Background}

Triggering receptor expressed on myeloid cells 2 (TREM2) is part of the immunoglobulin-lectin-like receptor superfamily, and in the brain, TREM2 is expressed mainly in microglial cells. TREM2 couples to DNAX-activating protein of $12 \mathrm{kDa}$ (DAP12) and activates its downstream targets through the phosphorylation of the immunoreceptor tyrosine-based activation motif (ITAM) of DAP12. TREM2 function has been related to phagocytosis, cell growth, regulation of actin cytoskeleton, migration towards chemokines, and cytokine release (reviewed in $[1,2])$. The inheritance of a mutant variant of the TREM2 gene, $R 47 \mathrm{H}$,

\footnotetext{
* Correspondence: lars.nilsson@medisin.uio.no

${ }^{1}$ Department of Pharmacology, Institute of Clinical Medicine, University of Oslo and Oslo University Hospital, Postboks 1057 Blindern, 0316 Oslo, Norway

Full list of author information is available at the end of the article
}

confers a markedly increased risk for developing late-onset $[3,4]$ and early-onset [5] Alzheimer's disease (AD). TREM2 expression has been found in the close vicinity of amyloid plaques in AD brain and transgenic mouse models, particularly in microglia and infiltrating macrophages surrounding plaques [6, 7]. Moreover, loss-of-function mutations in TREM2 are linked to an increased risk of developing Nasu-Hakola disease, frontotemporal dementia, Parkinson's disease, and sporadic amyotrophic lateral sclerosis [8-13]. This suggests a significant role for TREM2 in neurodegenerative diseases with phenotypes being dependent upon the location of the mutation and the severity of protein dysfunction [14]. Since TREM2 variants seem broadly involved in neurodegeneration, there is an urgent need to further investigate the functions of TREM2 in the brain and to find ligands involved in TREM2mediated signaling and their role in $\mathrm{AD}$ pathogenesis. 
Another strong risk factor for developing late-onset $\mathrm{AD}$ is the $\varepsilon 4$ allele of the apolipoprotein $\mathrm{E}$ gene $(A P O E)$, which is far more prevalent than the R47H-TREM2 risk factor [3]. The three major isoforms of ApoE in human are the ApoE $\varepsilon 2$ (cys112, cys158), ApoE \&3 (cys112, $\arg 158)$, and ApoE $\varepsilon 4$ (arg112, arg158). The most common isoform is ApoE ع3, while ApoE $\varepsilon 2$ isoform is rare. The APOE4 allele increases the risk of $\mathrm{AD}$ by three- to fourfold [15, 16], while APOE2 is protective [17]. The disease risk is gene dose-dependent for both alleles [15-17]. In the brain, astrocytes are the main source of ApoE, and ApoE is the major regulator of lipid metabolism, transporting cholesterol and phospholipids between cells (reviewed in [18]). ApoE is intimately associated with fibrils of amyloid- $\beta(A \beta)$ in amyloid deposits in AD brain and transgenic animal models of $\mathrm{AD}[16,19,20]$. Early studies reported both inhibition and augmentation of $A \beta$ fibril formation when mixing $A p o E$ and $A \beta$ in vitro [21-25]. Some studies reported that the ApoE \&4 isoform bound faster to $A \beta$ and increased aggregation more readily than the ApoE $\varepsilon 2$ or $\varepsilon 3$ isoforms [23, 25-27]. The interpretation of such studies in relation to the brain is complicated by the complex nature of $\mathrm{A} \beta$ (mixture of different lengths and aggregation states) and ApoE (isoform and lipidation state), which is difficult to mimic in vitro. A link between human ApoE and amyloid plaque accumulation in amyloid- $\beta$ precursor protein $(\mathrm{A} \beta \mathrm{PP})$ transgenic mouse brain has been consistently found [28-30]. Since mice have an ApoE isoform distinct from the human isoforms, these studies have mostly been done on A $\beta P P$ transgenic mice crossed with Apoe knockout mice $\left(A p o e^{-/-}\right)$instead expressing human $A P O E$. Such studies have shown that murine ApoE augments $A \beta$ deposition more than either of the human ApoE isoforms and that the order of fibrillogenic effect on $\mathrm{A} \beta$ of the human ApoE isoforms is $\mathrm{ApoE}$ $\varepsilon 4>\operatorname{ApoE} \varepsilon 3>\operatorname{ApoE} \varepsilon 2[28,31,32]$. These results are consistent with the relative risk associated with the ApoE variants for developing $\mathrm{AD}$. The effect of ApoE on $\mathrm{A} \beta$ aggregation also depends on the human ApoE concentration [30], as also reported for murine ApoE in the first A $\beta \mathrm{PP} /$ ApoE cross-breeding study [33].

All three main human ApoE isoforms were recently found to bind to human TREM2 in vitro [34, 35]. In a recent paper, these findings were partly opposed, as binding could not be detected between human TREM2 and nonlipidated human ApoE using protein microarray, while lipidated human ApoE bound TREM2 when biolayer interferometry was used [36]. The reported experiments were all done in pure in vitro (cell-free) settings [34-36]. It remains unclear whether ApoE binds to TREM2 when it resides on cell surfaces, and whether ApoE serves as a TREM2 agonist. Experimental proof of such an interaction would effectively link the two major genetic risk factors for AD in a signaling pathway.
In this study, we used a cell reporter assay to provide the first evidence of human ApoE-mediated intracellular signaling through human TREM2, which is of great importance for understanding of the interaction between ApoE and TREM2 in the AD pathogenesis. Possible interactions between human ApoE and murine TREM2 have never been examined despite multiple studies using transgenic A $\beta$ PP mice expressing human ApoE instead of murine ApoE. We report that human ApoE signals through murine TREM2, albeit with a reduced efficacy. The $K_{\mathrm{d}}$ has previously only been determined for the ApoE $\varepsilon 3$ isoform using dot blotting [34], a semi-quantitative method. We developed a sensitive ELISA-based binding assay to determine the affinity of human TREM2 binding to the three major human ApoE isoforms and, importantly, identified a TREM2binding region in human ApoE, which has never been reported before.

\section{Methods \\ Reagents}

Transparent Maxisorp 96-well plates (\#442404), Roswell Park Memorial Institute 1640 medium (RPMI; \#61870044), Zeocin (\#R250-01), ionomycin (\#I-24222), 2mercaptoethanol (\#31350-010), ethylenediaminetetraacetic acid (EDTA; \#15575-020), trypan blue (\#T10282), as well as secondary horseradish peroxidase (HRP)-conjugated rabbit anti-goat (\#31402) and goat anti-mouse (\#31430) antibodies were from Thermo Fischer Scientific (Waltham, MA, USA). Phorbol myristate acetate (PMA; \#P1585), chlorophenol-red $\beta$-D-galactopyranoside (CPRG; \#59767), magnesium chloride hexahydrate (\#M9272), potassium chloride (\#P5405), sodium phosphate dibasic dehydrate (\#30412), sodium chloride (\#71376), phosphatebuffered saline (PBS, pH 7.4; \#P4417), sodium dodecyl sulfate (SDS; \#L4390), Roche complete protease inhibitors (\#04-693-116-001), fetal bovine serum (FBS; \#F7524), and bovine serum albumin (BSA; \#A7030) were from SigmaAldrich (St. Louis, MO, USA). Monoclonal antibodies against $\beta$-actin (clone AC-15) and FLAG-peptide sequence DYKDDDDK (M2; \#F1804) were also from SigmaAldrich. Molecular biology grade 2-mercaptoethanol (\#A1108) was from AppliChem (Darmstadt, Germany). Electran 1,4-dithiothreithol (Cleland's reagent, DTT; \#443853B) and KPL LumiGLO kit (\#54-71-00) were from VWR (Radnor, PA, USA). 7.5 and 12\% TGX polyacrylamide gels (Mini-protean; \#4561026 and \#4561043, respectively) were from Bio-Rad (Hercules, CA, USA). Saponin (\#558255) and polyclonal goat anti-ApoE antibody (\#178479) were from Merck Millipore (Darmstadt, Germany). Polyclonal goat anti-TREM2 antibody (\#ab95470), preadsorbed unconjugated polyclonal rabbit anti-rat antibody (\#ab102248) and secondary HRPconjugated donkey anti-goat antibody (\#ab7125) were 
from Abcam (Cambridge, UK). Recombinant human ApoE ع2, ApoE ع3, and ApoE ع4 (\#4760, \#4696, and \#4699, respectively) were bought from BioVision (Milpitas, CA, USA). Recombinant human TREM2 (\#11084-H08H) and mouse TREM2 (\#50149-M08H) were bought from Sino Biological Inc. (Beijing, China). An ApoE-mimetic peptide corresponding to amino acids 130-149 (acetylTEELRVRLASHLRKLRKRLL-amide) and a scrambled peptide serving as negative control (acetyl-LREKKLRVSALRTHRLELRL-amide) were from GenScript (Piscataway, NJ, USA). K-blue aqueous substrate (TMB; \#331177) was bought from ANL-Produkter (Älvsjö, Sweden). Monoclonal rat antibodies were made towards TREM2 (clone 150; [37]) and $\mathrm{T}$ cell immunoglobulin domain and mucin domain 2 (TIM2) (clone N3-4; [38]).

\section{Reporter cell lines}

To investigate stimulation of TREM2 by ApoE, we used a reporter cell line based on $\mathrm{T}$ lymphocytes in which the $\alpha$ - and $\beta$-beta chains of the endogenous $\mathrm{T}$ cell receptor had been knocked out, and the cells expressed lac $Z$ under a nuclear factor of activated $\mathrm{T}$ cells (NFAT) promotor in an overexpression system [39, 40]. The cells were used to generate the reporter cells that also express human or murine TREM2. Here, TREM2 was linked in a single transmembrane fusion construct to a chimeric antigen receptor with the leader sequence and transmembrane CD8 domain fused with the intracellular CD3ל. When an agonist binds to TREM2, the ITAMs of

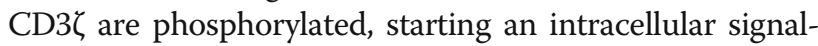
ing cascade through zeta-chain-associated protein kinase 70 (ZAP-70) thereby increasing the intracellular $\mathrm{Ca}^{2+}$ concentration. This resembles the physiological signaling of TREM2 through DAP12, in which ITAM-phosphorylation also recruits ZAP-70 [41]. The NFAT promotor is activated in response to the increased intracellular $\mathrm{Ca}^{2+}$ concentration $[39,40]$ such that $\beta$-galactosidase is expressed. Since $\beta$-galactosidase is expressed as a result of TREM2 signal transduction and NFAT promoter activity, we can determine the level of TREM2-stimulation by measuring the product generated by a colorimetric $\beta$-galactosidase substrate, CPRG (Fig. 1).

All cells were grown in RPMI supplemented with $1 \%$ penicillin + streptomycin, 5\% FBS, $50 \mu \mathrm{M}$ EDTA, and $50 \mu \mathrm{M} 2$-mercaptoethanol (termed cRPMI) in a cell incubator with $37{ }^{\circ} \mathrm{C}$ and $5 \% \mathrm{CO}_{2}$. The BWZ.36 cells are

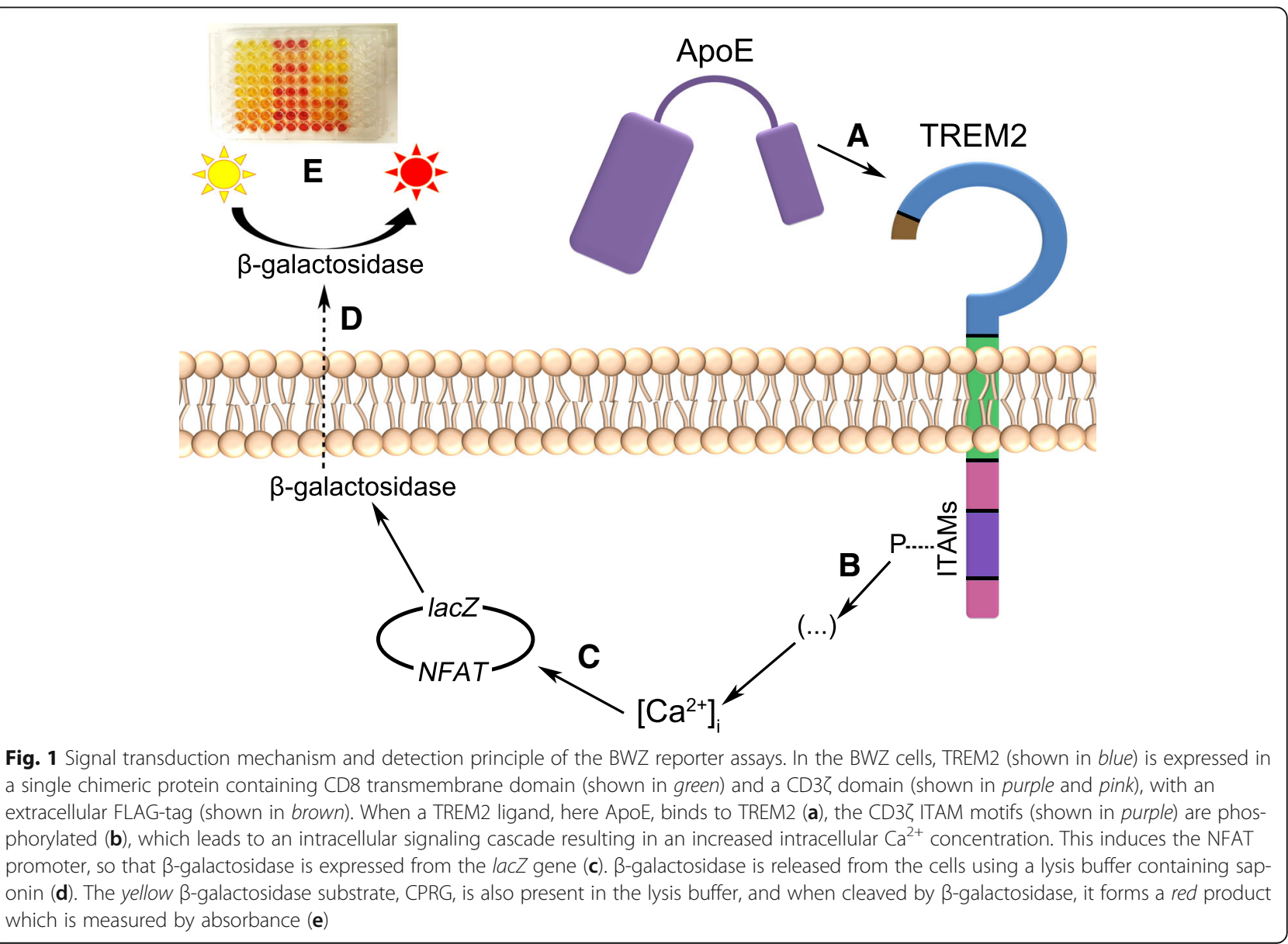


based on an immortalized T lymphocyte cell line [39, 40] and constitutively express 3xNFAT/LacZ. Naïve BWZ.36 cells were transfected by electroporation with human

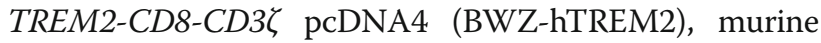

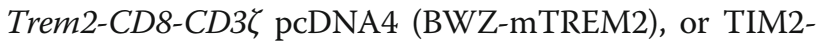

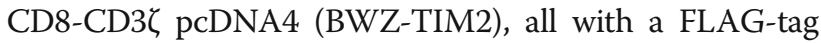
sequence incorporated as described elsewhere [37, 38]. TIM2 shows partial homology to the Ig domain of TREM2 [38]. Successfully transfected cells were selected with Zeocin $(0.75 \mathrm{mg} / \mathrm{mL})$.

\section{Reporter assays}

For testing stimulation of human and murine TREM2, we used a modified version of a reporter cell assay originally described by Sanderson and Shastri [40]. Cells used in reporter assays were counted using 0.2\% trypan blue and Invitrogen Countess automated cell counter (Thermo Fischer Scientific) and used only if the viability was above $90 \%$.

Transparent Maxisorp 96-well plates were used for the reporter assays. All coatings were done for $1 \mathrm{~h}$ at $37^{\circ} \mathrm{C}$ in sterile, special $\mathrm{PBS}$ with reduced ionic strength (S-

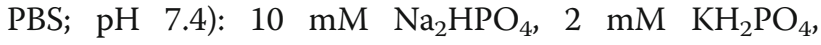
$13.7 \mathrm{mM} \mathrm{NaCl}$, and $0.27 \mathrm{mM} \mathrm{KCl}$. The wells of the plate were coated either with $2.5 \mu \mathrm{g} / \mathrm{mL}$ preadsorbed, unconjugated polyclonal rabbit anti-rat antibody, recombinant human ApoE ع2, ApoE ع3, or ApoE ع4 (3-300 nM diluted in S-PBS), or S-PBS alone. Between coating and adding BWZ cells to the plate $\left(2.4 \times 10^{5}\right.$ cells in cRPMI per well), the wells were carefully washed once with sterile S-PBS. All BWZ cells were mixed with different stimuli together with $3.3 \mathrm{nM}$ PMA as a costimulating agent and incubated for $4 \mathrm{~h}$ in a cell chamber with $37^{\circ} \mathrm{C}$ and $5 \% \mathrm{CO}_{2}$. The stimuli used were 3.7 or $5.2 \mathrm{nM}$ monoclonal rat anti-TIM2 antibody [38] or $3.3 \mathrm{nM}$ monoclonal rat anti-TREM2 antibody ("ab150"). The Ab150 antibody, also called clone 150.1, was produced at the same time as clone 78.18 referenced in [42], although ab150 (clone 150.1) is subclass IgG2a, while 78.18 is IgG1 [43]. Clone 150.1 detects both human and murine TREM2 in flow cytometry (unpublished data) and stimulates both human and murine TREM2 in our reporter assays. Thus, ab150 was used as a positive control for TREM2 receptor signaling, while the anti-TIM2 antibody was used as a positive control for TIM2 receptor signaling. After incubation with the stimuli, the cells were carefully washed once with $\mathrm{Hi}$-S-PBS (high phosphate content and low saline content: $60.7 \mathrm{mM} \mathrm{Na} \mathrm{HPO}_{4}, 13.2 \mathrm{mM}$ $\mathrm{KH}_{2} \mathrm{PO}_{4}, 0.27 \mathrm{mM} \mathrm{KCl}$, and $13.7 \mathrm{mM} \mathrm{NaCl}$ ). Finally, freshly prepared lysis buffer with CPRG substrate was added to the wells: $3 \mathrm{mM}$ CPRG in Hi-S-PBS with $5 \mathrm{mM}$ DTT, $20 \mathrm{mM} \mathrm{MgCl}$, and $0.2 \%(w / v)$ saponin. Volumes of added cells, coating solutions, washing solutions, and lysis buffers were all $200 \mu \mathrm{L} /$ well.
The absorbance was monitored from once the enzymatic reaction had started and onwards for $4 \mathrm{~h}$ at $570 \mathrm{~nm}$ (specific signal) and $700 \mathrm{~nm}$ (background) with a SpectraMax 190 plate reader (Molecular Devices). The plate was tightly sealed and placed gently shaking at $37^{\circ} \mathrm{C}$ between measurements. The absorbance at $\lambda_{700} \mathrm{~nm}$ background was subtracted from the specific signal at $\lambda_{570 \mathrm{~nm}}$ when processing the data. All results presented in this paper are from $4 \mathrm{~h}$ after adding the CPRG-containing lysis buffer to the stimulated cells. All measurements were made in triplicate.

\section{Protein extraction and western blot}

BWZ reporter cells, 14-month-old nontransgenic C57BL/ $6 \mathrm{~J}$ mouse brain, and 6-month-old Trem2-knockout mouse brain were extracted with a Potter-Elvehjem homogenizer (\#432-5015; VWR) by manual homogenization on ice with two times of ten strokes in ice-cooled 1\% $(w / v)$ SDS in $20 \mathrm{mM}$ Tris- $\mathrm{HCl}(\mathrm{pH} 7.5), 137 \mathrm{mM} \mathrm{NaCl}$, and $4 \mathrm{mM}$ EDTA with complete protease inhibitors. The resulting homogenate was centrifuged at 100,000 $g$ for $1 \mathrm{~h}$ at $+4{ }^{\circ} \mathrm{C}$ in a Beckman Optima LE-80 K ultracentrifuge with a Sw$60 \mathrm{Ti}$ rotor. After centrifugation, the supernatant was stored at $-80^{\circ} \mathrm{C}$ until use. SDS-protein extracts $(30-50 \mu \mathrm{g}$ total protein) were mixed with Laemmli buffer containing $\beta$-mercaptoethanol $\left(\begin{array}{ll}1 \% & v / v)\end{array}\right)$ and bromophenol blue (62.5 mg/L), heat-denatured at $75^{\circ} \mathrm{C}$ for $5 \mathrm{~min}$, and separated by electrophoresis at $160 \mathrm{~V}$. Proteins were transferred to nitrocellulose membranes with Trans-Blot semidry transfer system at $20 \mathrm{~V}$ for $30 \mathrm{~min}$. The filters were blocked for $1 \mathrm{~h}$ at $37{ }^{\circ} \mathrm{C}$ with $5 \%(w / v)$ non-dry milk powder in a Tris-buffered saline (TBS) buffer containing $0.1 \%$ Tween-20 before being incubated with primary antibodies recognizing either murine TREM2 $(0.1 \mu \mathrm{g} / \mathrm{mL})$ or FLAGtag M2-epitope $(1 \mu \mathrm{g} / \mathrm{mL})$ overnight at $4{ }^{\circ} \mathrm{C}$. The membranes were then incubated $30 \mathrm{~min}$ at room temperature (RT) with secondary rabbit anti-goat $(0.08 \mu \mathrm{g} / \mathrm{mL})$ or goat anti-mouse $(0.08 \mu \mathrm{g} / \mathrm{mL}) \mathrm{HRP}$-conjugated antibodies. The immunoreactive bands were visualized with enhanced chemiluminescence substrate using a LumiGLO kit. After stripping of the membranes, they were incubated for $30 \mathrm{~min}$ at RT with an antibody against $\beta$-actin (1:25000 dilution), followed by $30 \mathrm{~min}$ incubation at RT with secondary goat anti-mouse $(0.08 \mu \mathrm{g} / \mathrm{mL}) \mathrm{HRP}$-conjugated antibody and development with LumiGLO. Optical densities of the immunoreactive bands were quantified with Image Pro Plus (Media Cybernetics, Rockville, MD, USA). Western blots were performed two to three times, and representative images are shown.

\section{In vitro binding assay}

Transparent Maxisorp 96-well plates were coated with recombinant human TREM2 $(40 \mathrm{nM})$ on a shaking platform for $1 \mathrm{~h}$ at $37{ }^{\circ} \mathrm{C}$ in sterile PBS (pH 7.4). The plates 
were blocked with $1 \%(w / v)$ BSA (fatty acid free) in PBS for $1 \mathrm{~h}$ at $37^{\circ} \mathrm{C}$ before being incubated with recombinant human $\operatorname{ApoE}(\varepsilon 2, \varepsilon 3$, or $\varepsilon 4)$ at various concentrations for $1 \mathrm{~h}$ at RT. The plates were then incubated for $1 \mathrm{~h}$ at RT with $12 \mathrm{ng} / \mathrm{mL}$ polyclonal goat anti-ApoE antibody followed by $1 \mathrm{~h}$ at RT with $20 \mathrm{ng} / \mathrm{mL}$ donkey anti-goat HRP-conjugated antibody. Finally, the assay was developed with K-blue aqueous substrate (TMB) for $15 \mathrm{~min}$ at $\mathrm{RT}$, and the reaction was stopped with $1 \mathrm{M} \mathrm{H}_{2} \mathrm{SO}_{4}$. Absorbance was measured at $450 \mathrm{~nm}$ with a SpectraMax 190 plate reader (Molecular Devices). The plates were washed between each step with PBS with $0.05 \%(w / v)$ Tween-20.

\section{In vitro competition assay}

Transparent Maxisorp 96-well plates were coated with recombinant human TREM2 (40 $\mathrm{nM}$ in sterile PBS) shaking for $90 \mathrm{~min}$ at $37{ }^{\circ} \mathrm{C}$. The plates were blocked $1 \mathrm{~h}$ on a shaking platform at $37{ }^{\circ} \mathrm{C}$ with $1 \%(w / v)$ BSA (fatty acid-free) in PBS before being incubated $1 \mathrm{~h}$ at RT on a shaking platform with $6 \mathrm{nM}$ recombinant human $\operatorname{ApoE}(\varepsilon 2, \varepsilon 3$, or $\varepsilon 4)$ and various concentrations of ApoE-mim149 or scrambled peptide $(0-6 \mu \mathrm{M})$. For detection of ApoE bound to TREM2, a polyclonal goat anti-ApoE antibody $(18 \mathrm{ng} / \mathrm{mL})$ was used that only detects full-length ApoE, but not ApoE-mim149 or scrambled peptide (Additional file 1: Figure S1) and incubated $1 \mathrm{~h}$ on shaker at RT followed by incubation with a donkey anti-goat HRP-conjugated antibody ( $33 \mathrm{ng} / \mathrm{mL}$ ) for 30 min on shaker at RT. The assay was developed with K-blue aqueous substrate (TMB) for $30 \mathrm{~min}$ at RT, and the reaction was stopped with $1 \mathrm{M} \mathrm{H}_{2} \mathrm{SO}_{4}$. Absorbance was measured at $450 \mathrm{~nm}$ with a SpectraMax 190 plate reader (Molecular Devices).

\section{Statistics}

All experiments were performed three times with triplicates unless otherwise stated. GraphPad Prism vs. 5.04 (San Diego, CA, USA) was used for graphs and statistical analyses. For analyzing dose-response and binding curves, data from at least three independent experiments were pooled and normalized. Normalization of all data was done using the formula $Y=((X-L) /(K-L))^{*} 100 \%$ (in which $Y$ represents the normalized data point, $X$ represents the raw data point, $L$ represents the mean of the $0 \%$ data point, which was the lowest concentration of ApoE used, and $K$ represents the mean of the $100 \%$ data point with highest signals). $K_{\mathrm{d}}, \mathrm{EC}_{50}$, and Hill coefficients were calculated using the "log (agonist) vs. normalized response (variable)" function and were compared using oneway ANOVA with Bonferroni post-test. For the competition assay between full-length ApoE and ApoE-mim149, the $K_{\mathrm{i}}$ values were found by using the "one site-fit $K_{\mathrm{i}}$ " function with $6 \mathrm{nM}$ set as HotNM for all isoforms, and
HotKdNM set as the respective ApoE isoform $K_{\mathrm{d}}$ values calculated in the binding assay. For comparing effects of adding ApoE-mim149 to full-length ApoE, data points were compared individually using an unpaired $t$ test for each ApoE-mim149 concentration. All reported $p$ values are two-tailed.

\section{Results \\ ApoE $\varepsilon 3$ stimulates human TREM2-, but not TIM2- transfected reporter cells}

We wanted to investigate whether stimulation with the most common human ApoE isoform, ApoE ع3, would induce human TREM2 signaling. For this, reporter cells were generated with TREM2-CD8-CD3C and NFAT/lacZ constructs. When an agonist binds to TREM2 in these cells, an intracellular signaling cascade is initiated through the ITAM motif of CD3 . As a result of extracellular TREM2-stimulation, $\beta$-galactosidase expression is induced by the NFAT promoter (Fig. 1). A colorimetric CPRG-assay was used to detect TREM2 signal transduction in the reporter cells. We compared stimulation of BWZ-hTREM2 cells to that of TIM2-transfected cells. TIM2 shows partial homology to the Ig domain of TREM2; the production of the cells is described in [38]. All cells were stimulated with PMA, and cells that were PMA-stimulated, but not incubated with any other stimuli, were used as negative controls. An anti-TREM2 antibody was used as positive control for stimulation of BWZ-hTREM2 receptor signaling. An anti-TIM2 antibody was used as positive control for stimulation of BWZ-TIM2 receptor signaling. We found that ApoE $\varepsilon 3$ was an agonist for human TREM2 (Fig. 2) and demonstrated a dose-dependent signaling effect in BWZhTREM2 cells that markedly differed from BWZ-TIM2 cells. As might be noted in Fig. 2, the cells displayed a weak dose-dependent ApoE-mediated background ( $p<$ $0.05)$ that was independent of transfection with TREM2. This background was likely caused by ApoE acting on other receptors on the $\mathrm{T}$ lymphocytes, such as the lowdensity lipoprotein receptor (LDLR) [44-46], possibly resulting in a minor increase in the intracellular $\mathrm{Ca}^{2+}$ concentration. However, the potential background effects of stimulation of other receptors are small in comparison to stimulation of TREM2.

\section{ApoE $\varepsilon 2, A p o E \varepsilon 3$, and ApoE $\varepsilon 4$ are all agonists for both human and murine TREM2}

Next, we examined if the other two human isoforms of ApoE, $\varepsilon 2$ and $\varepsilon 4$, were likewise agonists for human TREM2. For ApoE stimulation of human TREM2, EC 50 was 27, 33, and $34 \mathrm{nM}$ for ApoE $\varepsilon 2$, ApoE $\varepsilon 3$, and ApoE $\varepsilon 4$, respectively (Fig. 3a; $\varepsilon 2-\log \mathrm{EC}_{50}=7.57 \pm 0.06 \mathrm{M}, \varepsilon 3$ $\left.-\log \mathrm{EC}_{50}=7.48 \pm 0.04 \mathrm{M}, \varepsilon 4-\log \mathrm{EC}_{50}=7.47 \pm 0.05 \mathrm{M}\right)$. There was no statistically significant difference in $\mathrm{EC}_{50}$ 


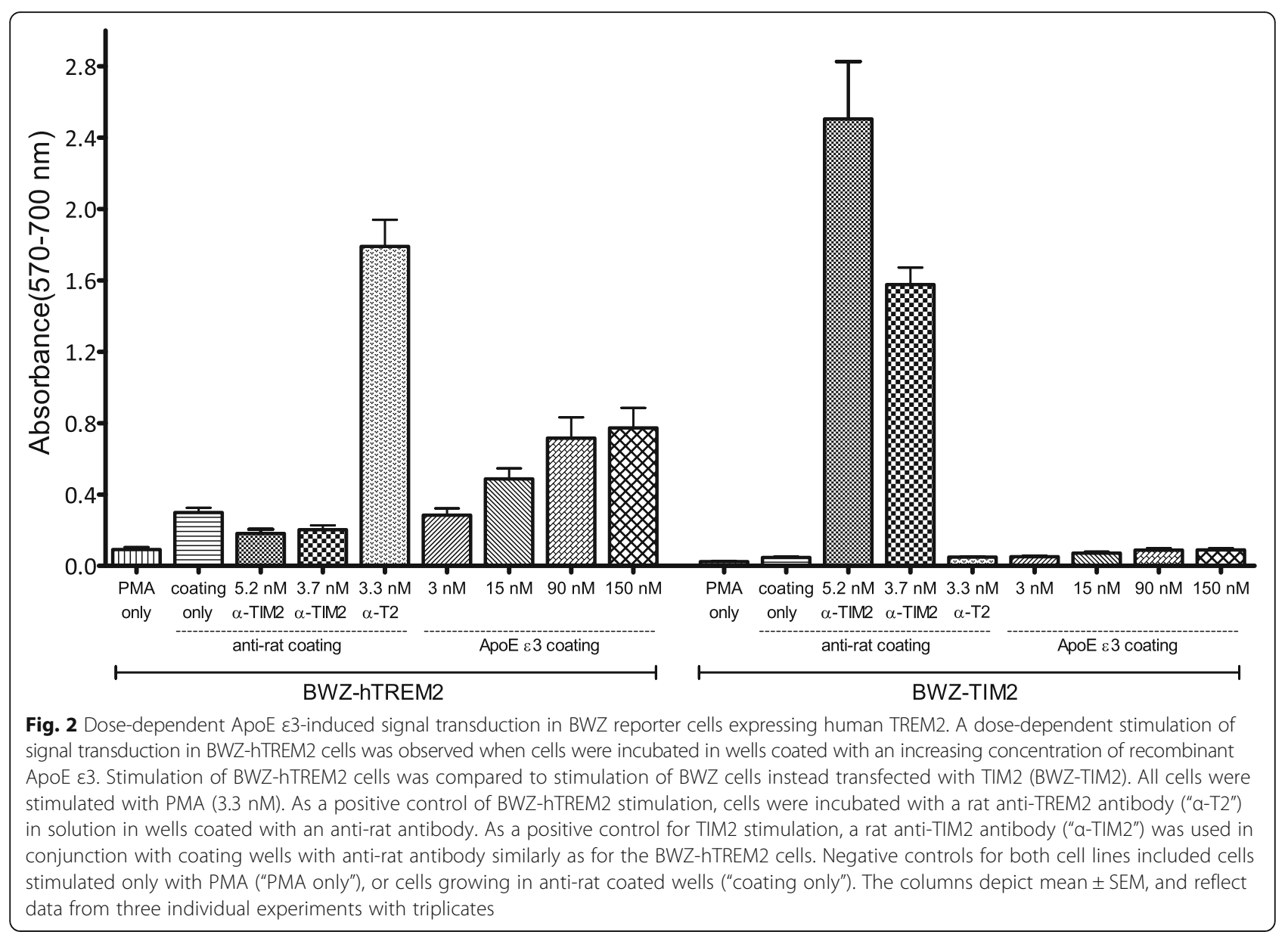

\section{A human TREM2}

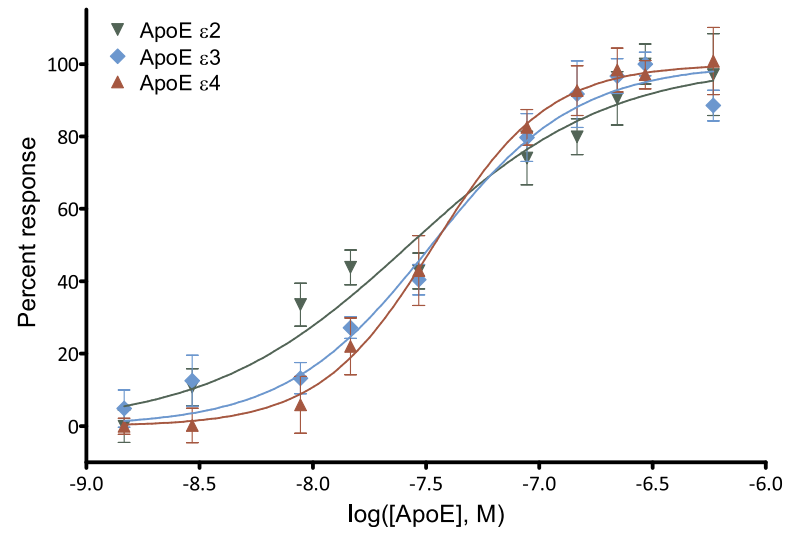

B murine TREM2

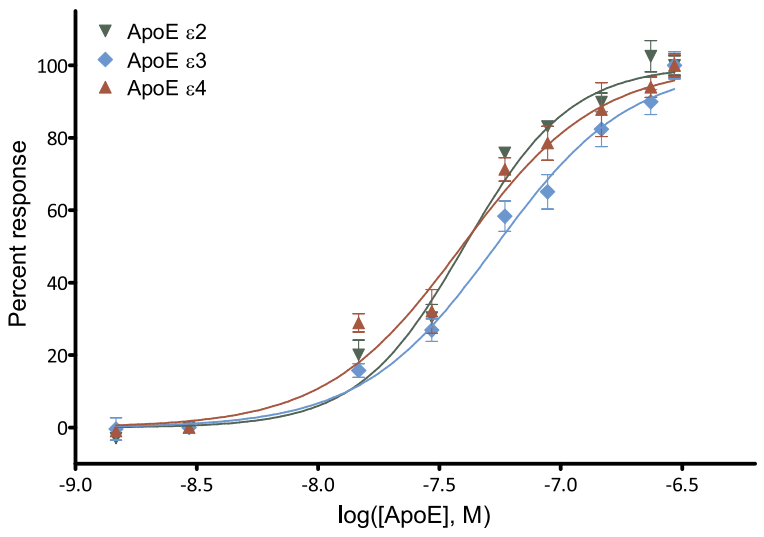

Fig. 3 The three human ApoE isoforms serve as agonists for human and murine TREM2. Human ApoE $\varepsilon 2$ (inverted green triangle), $\varepsilon 3$ (light blue diamond), and $\varepsilon 4$ (red triangle) all stimulated human (a) and murine (b) TREM2 receptor signal transduction in a dose-dependent manner. $\mathrm{EC}_{50}$ for human ApoE was 27, 33, and $34 \mathrm{nM}$ for ApoE $\varepsilon 2$, $\varepsilon 3$, and $\varepsilon 4$, respectively. EC 50 for murine TREM2 was 40, 54, and 39 for ApoE $\varepsilon 2$, $\varepsilon 3$, and $\varepsilon 4$, respectively. The points depict mean \pm SEM of all responses measured in triplicates from five (human TREM2) and three (murine TREM2) independent experiments. Data from each ApoE isoform was normalized individually as described in the "Methods" section. The scale of the $x$-axis is logarithmic and shows concentration of human ApoE in M 
between the isoforms. We also performed the same experiments with murine TREM2 and determined $\mathrm{EC}_{50}$ for both human and murine TREM2. For murine TREM2, the $\mathrm{EC}_{50}$ was 40, 54, and $39 \mathrm{nM}$ for ApoE $\varepsilon 2$, ApoE $\varepsilon 3$, and ApoE $\varepsilon 4$, respectively (Fig. 3b; $\varepsilon 2-\log \mathrm{EC}_{50}=7.40 \pm$ $0.02 \mathrm{M}, \varepsilon 3-\log \mathrm{EC}_{50}=7.27 \pm 0.03 \mathrm{M}, \varepsilon 4-\log \mathrm{EC}_{50}=7.41 \pm$ $0.04 \mathrm{M})$. The $\mathrm{EC}_{50}$ was significantly higher for ApoE $\varepsilon 3$ than for ApoE $\varepsilon 2$ and $\varepsilon 4$ ( $p<0.001$ for both). There was no significant difference between ApoE $\varepsilon 2$ and ApoE $\varepsilon 4$ $(p>0.05)$. The dose-response curve for ApoE stimulation of human TREM2 showed Hill coefficients between 1 and 2 ( $221.0 \pm 0.1, \varepsilon 31.4 \pm 0.2, \varepsilon 41.7 \pm 0.2$ (Fig. 3a), with statistically significant difference between ApoE $\varepsilon 2$ and $\varepsilon 4$ $(p<0.001)$. The Hill coefficients for murine TREM2 were also between 1 and $2(2.0 \pm 0.1,1.6 \pm 0.1$, and $1.6 \pm 0.2$ for ApoE $\varepsilon 2$, $\varepsilon 3$, and $\varepsilon 4$, respectively) (Fig. 3b). There was no statistically significant difference between Hill coefficients of isoforms for murine TREM2 $(p>0.05)$.

In order to compare the expression levels of TREM2 in the BWZ-mTREM2 and BWZ-hTREM2 cells, western blots were semi-quantified with densitometry. We found that the expression level was $7.5 \%( \pm 0.2 \%)$ higher in BWZ-mTREM2 than in BWZ-hTREM2 cells (Fig. 4a), although the difference was not statistically significant $(p>0.05 ; n=2$ for each cell line). We furthermore found that TREM2 protein expression in an SDS extract of the BWZ cells was lower than that of a brain SDS extract from a 14-month-old nontransgenic C57BL/6J mouse $(\approx 1$ ng TREM2/ $\mu$ g total protein; Fig. $4 \mathrm{~b}, \mathrm{c})$. Only a faint co-migrating band was detected in the SDS-extract of Trem2-knockout mouse brain (Fig. 4b). The limitations of the western blot experiments are mentioned in the "Discussion" section.
ApoE $\varepsilon 2, A p o E \varepsilon 3$, and ApoE $\varepsilon 4$ bind to recombinant human TREM2 with high affinity

In order to determine affinity of the binding between ApoE and TREM2, we established an in vitro ELISAbased binding assay. Nonlipidated human ApoE bound to recombinant human TREM2 with high affinity. There were only small differences between isoforms with $K_{\mathrm{d}}$ of 13, 16, and $9.5 \mathrm{nM}$ for ApoE $\varepsilon 2$, ApoE $\varepsilon 3$, and ApoE ع4, respectively (Fig. 5; $\varepsilon 2-\log K_{\mathrm{d}}=7.87 \pm$ $0.02 \mathrm{M}, \varepsilon 3-\log K_{\mathrm{d}}=7.78 \pm 0.03 \mathrm{M}, \varepsilon 4-\log K_{\mathrm{d}}=8.02 \pm$ $0.03 \mathrm{M})$. The $K_{\mathrm{d}}$ of ApoE $\varepsilon 4$ was lower than the $K_{\mathrm{d}}$ of ApoE $\varepsilon 3(p<0.001)$ and ApoE $\varepsilon 2(p<0.001)$. The Hill coefficients were similar for ApoE $\varepsilon 2(1.4 \pm 0.1)$, ApoE $\varepsilon 3(1.3 \pm 0.1)$, and ApoE $\varepsilon 4 .(1.4 \pm 0.1)(p>0.05)$.

\section{Amino acids $130-149$ in human ApoE contain a binding domain for human TREM2}

Previously, it has been found that the human ApoE fragment "ApoE-mim149" (amino acids 130-149 of ApoE) modulates microglial immune response [47]. To investigate whether this region contains a binding domain for human TREM2, we let ApoE-mim149 peptide and ApoE compete for binding to human TREM2. Adding human ApoE and ApoE-mim149 simultaneously to recombinant, human TREM2 resulted in reduced binding of ApoE to TREM2 with an increasing concentration of ApoE-mim149 in the mixture $(p<0.001$ for all three ApoE isoforms at both $6 \mu \mathrm{M}$ and $0.6 \mu \mathrm{M}$ concentration of ApoE-mim149). This effect was not seen when instead an increasing concentration of a scrambled peptide (altered sequence of amino acids 130-149 of ApoE) was supplemented, indicating that a TREM2-binding region is present in amino acids 130149 of human ApoE (Fig. 6). The $K_{\mathrm{i}}$ values for the three
A BWZ-mTREM2 vs. BWZ-hTREM2

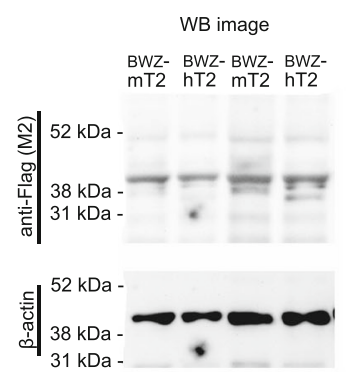

B BWZ-mTREM2 vs. mouse brain

C mouse brain TREM2

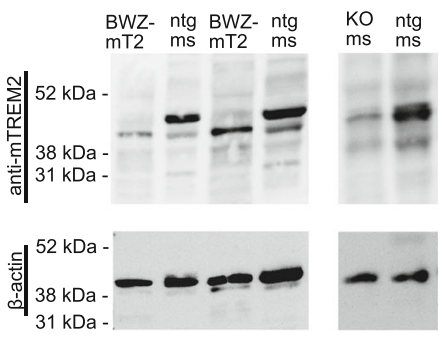

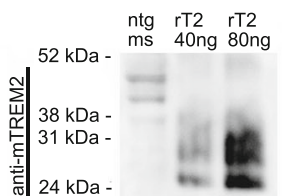

Fig. 4 Rougly similar level of TREM2 in BWZ-mTREM2 and hTREM2 cells and lower than in mouse brain. a In both the BWZ-mTREM2 and BWZ-hTREM2 reporter cells, the TREM2 constructs harbor a FLAG-tag. A western blot with an antibody detecting the FLAG-tag expression in the reporter cells indirectly showed that the TREM2 level was slightly higher in the BWZ-mTREM2 than in the BWZ-hTREM2 cells, although this was not statistically significant ( $n=2$ for both cell lines). Protein loading was $30 \mu \mathrm{g}$ (lanes 1-2) and $50 \mu \mathrm{g}$ (lanes 3-4). b Western blot detection of murine TREM2 in BWZ-mTREM2 cells ("BWZ-mT2") compared to a nontransgenic mouse brain ("ntg ms"). Protein loading was $30 \mu \mathrm{g}$ (lanes 1-2) and $50 \mathrm{\mu g}$ (lanes 3-4). TREM2 in the nontransgenic mouse brain was also compared to Trem2 knockout mouse brain ("KO ms"). Protein loading was $40 \mu \mathrm{g}$ in both lanes. c The level of TREM2 protein in the nontransgenic mouse brain was estimated to approximately $1 \mathrm{ng} / \mu \mathrm{g}$ protein by using recombinant mouse TREM2 ("recT2") as a standard. Mouse brain extract (30 $\mathrm{\mu g}$ total protein) was loaded in lane 1, while 40 and $80 \mathrm{ng}$ pure, recombinant TREM2 was loaded in lanes 2 and 3, respectively 


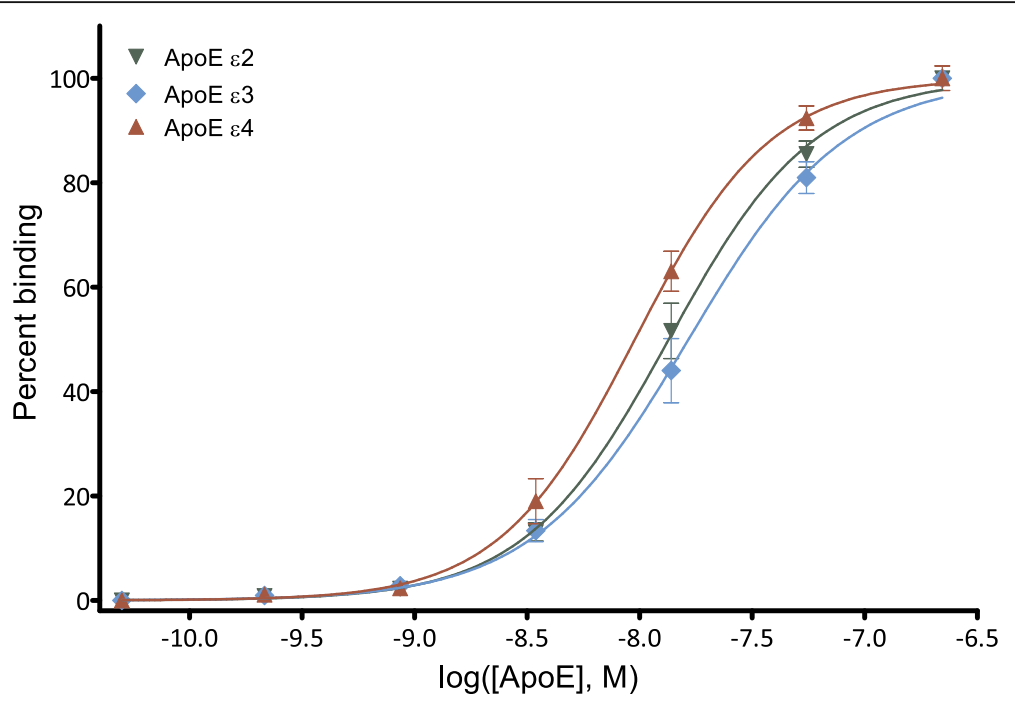

Fig. 5 High-affinity binding of recombinant human $A p o E \varepsilon 2, \varepsilon 3$, and $\varepsilon 4$ to recombinant human TREM2. In an ELISA-based binding assay with recombinant human TREM2 and recombinant human ApoE, ApoE $\varepsilon 2$ (inverted green triangle), ApoE $\varepsilon 3$ (light blue diamond), and ApoE $\varepsilon 4$ (red triangle) isoforms bound to human TREM 2 in vitro with $K_{d}$ of 13,16 , and $9.5 \mathrm{nM}$, respectively. The points depict mean \pm SEM of all responses that were measured in triplicates from three independent experiments. Data from each ApoE isoform was normalized individually as described in the "Methods" section. The $x$-axis shows the ApoE concentrations (in M) on a logarithmic scale

ApoE $\varepsilon 2, \varepsilon 3$, and $\varepsilon 4$ with ApoE-mim149 present were 827, 475 , and $1537 \mathrm{nM}$, respectively $\left(\varepsilon 2-\log K_{\mathrm{i}}=6.08 \pm 0.1 ; \varepsilon 3\right.$ $\left.-\log K_{\mathrm{i}}=6.32 \pm 0.1 ; \varepsilon 4-\log K_{\mathrm{i}}=5.81 \pm 0.1\right)$. The $K_{\mathrm{i}}$ for ApoE $\varepsilon 4$ was significantly higher than for ApoE $\varepsilon 3(p<0.001)$.

\section{Discussion}

APOE and TREM2 are the two most predominant genetic risk factors in AD. Previous papers have reported binding between human ApoE and human TREM2 only in pure in vitro settings [34-36], but did not contain investigations on whether $\mathrm{ApoE}$ was an agonist mediating intracellular signaling through TREM2, or alternatively an antagonist inhibiting other stimuli. In this study, using cell reporter assays, we provide the first evidence that ApoE and TREM2 interact in a signaling pathway. With a sensitive ELISA-based binding assay, we have determined binding affinities of human $\mathrm{ApoE} \varepsilon 2$, $\varepsilon 3$, and $\varepsilon 4$ to human TREM2 to be in the low $\mathrm{nM}$ range. Importantly, we report the first evidence that a TREM2-binding domain is found in amino acids 130-149 of human ApoE, which is the conserved receptor-binding domain in the main ApoE isoforms, $\varepsilon 2$, $\varepsilon 3$, and $\varepsilon 4$, as reviewed in [48].

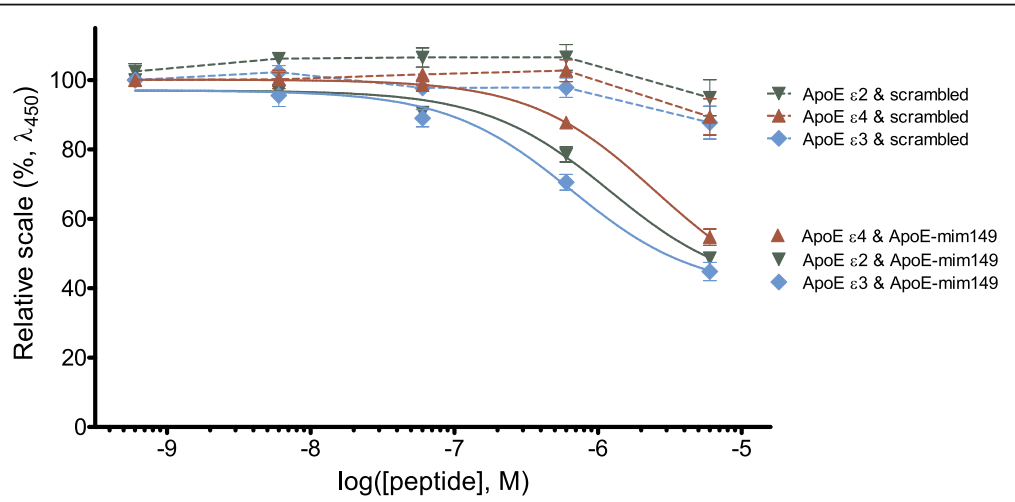

Fig. 6 An ApoE-mimetic peptide (amino acids 130-149) reduced binding of human ApoE to human TREM2. An ApoE-mimetic (amino acids 130-149) or a scrambled peptide was allowed to compete with ApoE for binding to immobilized recombinant human TREM2 in the ELISAbased assay. This led to reduced binding of ApoE, isoforms $\varepsilon 2$ (inverted green triangle), $\varepsilon 3$ (light blue diamond), and $\varepsilon 4$ (red triangle), to human TREM2 with $K_{\mathrm{i}}$ of 827,475 , and $1537 \mathrm{nM}$ for $\mathrm{ApoE} \varepsilon 2, \varepsilon 3$, and $\varepsilon 4$, respectively. The points depict mean \pm SEM of binding measured in duplicates from four independent experiments. The data was normalized to maximum (100\%), which is binding of ApoE in the absence of a competing peptide, and minimum (0\%), which is signal in the absence of ApoE as well as a TREM2-coat. The $x$-axis shows ApoE-mim149 or scrambled peptide concentration (in M) on a logarithmic scale 
By using an ELISA-based binding assay, we found a statistically significant lower $K_{\mathrm{d}}$ for ApoE $\varepsilon 4$ (9.5 nM) than for ApoE $\varepsilon 2$ and ApoE $\varepsilon 3$ (13 and 16 nM, respectively), while the $\mathrm{EC}_{50}$ for human TREM2-signaling was similar among the ApoE isoforms (27, 33, and $34 \mathrm{nM}$ for ApoE $\varepsilon 2, \varepsilon 3$, and $\varepsilon 4$, respectively). Since we found a TREM2-binding domain in a conserved region of ApoE (amino acids 130-149), it is reasonable to expect equal binding affinity between the recombinant human ApoE isoforms, as was also previously reported [34, 35]. The biological relevance of potential isoform differences in TREM2 stimulation, if any, needs to be further investigated by in vivo modeling. The $\mathrm{EC}_{50}$ data found are in the physiologically relevant range, since the ApoE concentration is between $60-300 \mathrm{nM}$ in the human cerebrospinal fluid (CSF) and 880-2700 nM in the plasma [49-53]. In the brain, it can generally be expected that the concentration of a given protein depends on location. The availability of a ligand to a receptor also depends on its binding to other proteins. Accordingly, ApoE is likely to be present in higher local concentrations in amyloid plaques and close to cell surfaces of astrocytes, and the CSF concentration gives only a rough estimate of the ApoE concentration in the brain. With western blots, we did not find evidence that TREM2 was overexpressed in the BWZ reporter cells as compared to the brain from a nontransgenic 14-month-old mouse. Using Trem2 knockout brain tissue, we showed that the immunoreactive band in tissue extract of the nontransgenic mouse brain is largely derived from murine TREM2. The major limitation with the western blot experiments is that the binding of the TREM2 antibody might depend on TREM2 glycosylation, which presumably differs between native TREM2 in mouse brain and TREM2 in transfected BWZ cells, and surely with nonglycosylated recombinant TREM2. The TREM2 antibody used was chosen since it was raised against a domain (amino acids 154-165 of mouse TREM2), which is distinct from the location of the $N$ glycosylation, which occurs at amino acids 20 and 80 [54]. Yet, it still cannot be excluded that differential glycosylation still plays a role. A $40-45-\mathrm{kDa}$ size of the TREM2 immunoreactive band from brain extract is quite consistent with previous observations [55]. Glycosylation structure and complexity affects migration of proteins on a polyacrylamide gel. The vector should encode a TREM2 fusion protein of $\approx 36 \mathrm{kDa}$, but since it is expressed in a cell line, the protein glycosylation is likely to be less complex than that of the native TREM2 protein in mouse brain.

By stimulating BWZ-hTREM2 reporter cells with ApoE, we found a significantly higher Hill coefficient for ApoE $\varepsilon 4$ (1.7) than for ApoE $\varepsilon 2$ (1.0). When using a sensitive ELISA-based binding assay, we found similar Hill coefficients between the ApoE isoforms when bound to recombinant, human TREM2. The relevance of binding differences needs to be further explored with other experimental techniques such as structural modeling of human TREM2 bound by ApoE isoforms.

It might be tempting to conclude that the risk of $\mathrm{AD}$ does not depend on ApoE/TREM2 signaling since we did not find evidence of ApoE isoform-dependent differences in binding to or signaling through TREM2. However, other factors could play a role in vivo: (1) It has been shown that the ApoE concentration in CSF depends on $A P O E$ genotype [51], making it plausible that individuals homozygous for APOE4 exhibit diminished stimulation of TREM2 as a result of lower ApoE concentration; (2) the outcome of the ApoE-mediated intracellular signaling through TREM2 could vary depending on ApoE isoforms due to cofactors with different binding affinities exerting effects on structure and stability, or perhaps even downstream targets of the intracellular signaling through TREM2. Thus, it is still possible that the ApoE/TREM2 interaction contributes to the ApoE isoform-dependent AD risk.

Ligand-induced receptor signaling also depends on interactions with other constituents in the membrane and on anchoring proteins. Heparan sulfate proteoglycan (HSPG) is a possible cofactor that could be involved in the ApoE stimulation of TREM2. HSPGs are ubiquitously present on cell surfaces and in extracellular matrices, and the heparan sulfate (HS) side chains can bind ApoE [56-58]. Interestingly, both the receptor-binding region and the lipid-binding region of ApoE are involved in binding to HS [57-63]. HSPGs are known to regulate the interaction between ligands and their receptors [64-67]. In this sense, ApoE $\varepsilon 2$ binds more readily to HS than ApoE $\varepsilon 3$ $[56,68]$, thus perhaps differentiating the ApoE $\varepsilon 2$-mediated activation of TREM2 from the ApoE $\varepsilon 3$-mediated activation. Interestingly, $\mathrm{HS}$ and ApoE are both present in amyloid plaques in AD and animal models [69-73].

Another possible cofactor for the ApoE/TREM2 signaling is $A \beta$. While $A \beta$ has been reported to bind both the lipid-binding region (amino acids 244-272) and the receptor-binding region (within amino acids 130-149) of ApoE $[26,74]$, it is interesting to note that $A \beta$ binding to the lipid-binding region of ApoE would allow for the possibility of stimulation of TREM 2 by the $A \beta / A p o E$ complexes found in or around amyloid plaques.

A link between ApoE and $\mathrm{A} \beta$ has been found consistently, as $A P O E$ dose-dependently enhances the risk of developing late-onset $\mathrm{AD}$ and also increases amyloid burden among those carrying $\varepsilon 4$ alleles $[15,75]$. Likewise, in $\mathrm{APP}^{\mathrm{V} 717 \mathrm{~F}}$ transgenic mice, the $\mathrm{ApoE} \varepsilon 4$ isoform was found to increase $A \beta$ deposition [28] and decrease A $\beta$ clearance [32], although the specific clearance pathway involved is still incompletely understood. In C57BL/6 mice, ApoE (lipid-poor or lipid-rich) and $\mathrm{A} \beta$ 
(monomeric $A \beta_{40}$ or $A \beta_{42}$ ) were injected intracerebrally either alone or in ApoE-A $\beta$ complexes. The authors found decreased $A \beta$ clearance associated with the ApoE $\varepsilon 4$ isoform [76]. Since ApoE is associated with $A \beta$ in amyloid plaques and TREM2 is found in microglia or macrophages adjacent to the plaques [6,7], it is intriguing to think that there might be a connection between $\mathrm{A} \beta / \mathrm{ApoE}$ complexes and TREM2 on surrounding microglia/macrophages.

While reduced ApoE gene dosage consistently ameliorates $\mathrm{AD}$ phenotypes [30,33], there has been conflicting reports on gene dosage effects of TREM2 in A $\beta P P$ transgenic mice $[7,77,78]$. Reduced TREM2 gene dosage was found to enhance amyloid pathology in one of the studies [78], while it decreased amyloid pathology in another study [7]. Importantly, the latter group recently showed that TREM2 deficiency in APP/PS1 mice lead to reduced amyloid burden at an early disease stage, while it enhanced amyloid burden at a late disease stage [79]. When $\mathrm{AD}$ pathogenesis is investigated in transgenic mouse models, human ApoE isoforms are often expressed, either by using a heterologous promoter [80] or by gene replacement in animals devoid of murine ApoE [81]. Knowing that the TREM2/ApoE interaction is presumably relevant to $\mathrm{AD}$ pathogenesis and perhaps also to other neurodegenerative diseases, we found it essential to determine the extent to which human ApoE stimulated murine TREM2 signaling. Such information is needed to better interpret studies with mouse models of disease. We found that all three human ApoE isoforms were agonists to murine TREM2 albeit with slightly reduced efficacy compared to human TREM2. Therefore, double transgenic ApoE/A $\beta P P$ animal models might inadequately reflect the interactions between ApoE and TREM2 in the AD brain; microglial activation triggered by ApoE stimulation of murine TREM2 might be more modest in transgenic mice than when TREM2 in AD brain is exposed to the same stimuli. Thus, it could be worth the effort to create human TREM2 knock-in models, or at least to insert exons encoding the extracellular domains of human TREM2 into the murine genome.

The ApoE/TREM2 interaction as observed by us might be involved in a clearance pathway, which is consistent with experiments with transgenic mice convincingly linking ApoE to $A \beta$ clearance $[28,32]$. ApoE could potentially also regulate responses of macrophages or microglia to specific stimuli of neuroinflammation and lipid metabolism and activate specific cellular functions such as phagocytosis. Microglia do not express TREM2 constitutively on the cell surface [82], thus complicating investigations of ligand-receptor interactions with primary cells in vitro. The reporter cells used here serve as an efficient and sensitive tool delivering reliable quantitative data on ligand-receptor interactions and signaling. However, there might be differences in the cell-surface expression of proteins or glycoproteins (possibly functioning as cofactors to TREM2) as well as intracellular signaling cascade between reporter cells and microglia/macrophages.

In the plasma, the ApoE isoforms differentially bind to lipids, with ApoE $\varepsilon 2$ and $\varepsilon 3$ preferring high-density lipoprotein (HDL) lipids and ApoE $\varepsilon 4$ preferring low-density lipoproteins (LDL) and very low-density lipoprotein (VLDL) lipids [48, 83-86]. However, the intact BBB of the adult brain confers a barrier through which neither lipoproteins nor lipids can pass, thus creating a restrictive environment that is distinct from the plasma. In this manner, LDL and VLDL are not present in the CNS, and the astroglial-derived HDL particles are structurally different from those found in the plasma (see [18] for a review on CNS lipoproteins). However, the lipoproteinaffecting enzymes, transporters, and receptors present in the periphery are also found in the CNS [18], and different binding affinities have been reported for the ApoE isoforms to their receptors, which can also be affected by ApoE lipidation state for some receptors [76, 87, 88]. Using reporter cells, it was recently found that various anionic lipids found in $\mathrm{AD}$ amyloid plaques were agonists for TREM2 [78]. Since ApoE is a lipid carrier, the ApoE/TREM2 interaction is likely to be involved in lipid sensing by TREM2 [78, 89], although we hereby demonstrate that the nonlipidated ApoE protein is sufficient for a high-affinity interaction. Initial studies of TREM2 ligand binding suggested that TREM2 could function as a pattern recognition receptor distinguishing negatively charged motifs [37]. In addition to ApoE binding, other apolipoproteins, ApoA1, ApoA2, ApoB, and ApoJ, also bind to TREM2 [34-36]. Binding of lipidated as well as nonlipidated human ApoE to human TREM2 has been demonstrated [34-36]. In our cell reporter assays, ApoE is bound to a Maxisorp plate, and it is unlikely that lipids from cells or FBS will lipidate ApoE under these circumstances. Also arguing against the necessity of ApoE being lipidated in order to bind TREM2 is our demonstration of high affinity binding between recombinant ApoE and recombinant TREM2 in a cell-free and lipid-free ELISA binding assay. Moreover, the doseresponse curves for in vitro binding data and reporter cell signaling data were quite similar, which further argues against lipidation of ApoE being necessary for TREM2 signaling. Finally, the ApoE fragment, ApoEmim149, binds to TREM2. This peptide is derived from the receptor-binding domain of ApoE, which is distinct from the lipid-binding domain [48]. It is conceivable that immobilization of ApoE to a plate can affect its conformation such that an ApoE conformer is created, which is prone to stimulate TREM2 in the reporter assay. However, ApoE interacting with TREM2 and 
displaying $\mathrm{EC}_{50}$ and $K_{\mathrm{d}}$ values in the same approximate concentration range when immobilized (reporter assay) and when in solution (binding and competition assays) argues that such a potential effect is either very limited or not relevant in our experiments.

\section{Conclusions}

In conclusion, we have proved the existence of a joint signaling pathway between TREM2 and ApoE, the proteins encoded by the two strongest genetic risk factors for $\mathrm{AD}$, and found that the human ApoE isoforms $\varepsilon 2$, $\varepsilon 3$, and $\varepsilon 4$ are all agonists to human and murine TREM2, albeit with reduced potency to murine TREM2. We have also determined binding affinities of the human ApoE isoforms to human TREM2 and identified a potential TREM2-binding domain in the receptor-binding region of human ApoE, which is conserved among the human isoforms. Our findings lay base for further studies on the pathophysiological relevance of the ApoE-dependent TREM2 receptor signaling. Within preclinical pharmacology, our work points out the need to develop new transgenic models with human TREM2 expression as to properly display the interplay between ApoE and TREM2 on AD phenotypes and to evaluate therapeutic strategies.

\section{Additional file}

Additional file 1: Supplementary Material. (DOCX 1372 kb)

\begin{abstract}
Abbreviations
AD: Alzheimer's disease; ApoE: Apolipoprotein E; Aß: Amyloid-beta; ABPP: Amyloid-beta precursor protein; BSA: Bovine serum albumin; CPRG: Chlorophenol-red $\beta$-D-galactopyranoside; CSF: Cerebrospinal fluid; DAP12: DNAX activating protein of 12 kDa; DTT: Electran 1,4-dithiothreithol; EDTA: Ethylenediaminetetraacetic acid; FBS: Fetal bovine serum; HDL: Highdensity lipoprotein; HRP: Horseradish peroxidase; HS: Heparan sulfate; HSPG: Heparan sulfate proteoglycan; ITAM: Immunoreceptor tyrosine-based activation motif; LDL: Low-density lipoprotein; LDLR: Low-density lipoprotein receptor; NFAT: Nuclear factor of activated T cells; PBS: Phosphate-buffered saline; PMA: Phorbol myristate acetate; RPMI: Roswell Park Memorial Institute 1640 medium; RT: Room temperature; SDS: Sodium dodecyl sulfate; TBS: Trisbuffered saline; TIM2: T cell immunoglobulin domain and mucin domain 2; TREM2: Triggering receptor expressed on myeloid cells 2; VLDL: Very lowdensity lipoprotein; ZAP-70: Zeta-chain associated protein kinase 70
\end{abstract}

\section{Acknowledgements}

We sincerely thank Prof. David M. Holtzman and Dr. Jason Ulrich (Department of Neurology, Washington University School of Medicine, St. Louis, MO, USA) for providing the brain tissue from the Trem 2 knockout mice.

\section{Funding}

This work was supported by a funding from the University of Oslo, Anders Jahres stiftelse, Helse Sør-Øst, Civitan Foundation, Norwegian Research Council (\#240316; Catharina De Lange Davies) and a JPND grant (APGeM - NFR \#237250; Tormod Fladby) to LNGN.

\section{Availability of data and materials}

The datasets analyzed in the current study are available from the corresponding author on a reasonable request.

\section{Authors' contributions}

MRD made the BWZ reporter cells and the anti-TREM2 (Ab150) and anti-TIM2 (N3-4) antibodies. CJ designed and optimized the protocol, performed, analyzed, and interpreted the data from BWZ reporter cell experiments. VÅ and LNGN performed the binding and competition assays. CJ, VÅ, and LNGN analyzed and interpreted the data from binding and competition assays. LNGN performed, analyzed, and interpreted the western blot experiments. VÅ performed and analyzed the control experiments (Additional file 1: Supplementary material). CJ wrote the manuscript and made the figures. CJ and LNGN critically revised the manuscript. All authors critically read and approved the final manuscript.

\section{Competing interests}

The authors declare that they have no competing interests.

\section{Consent for publication}

Not applicable.

\section{Ethics approval}

The animal experiments were done under the ethical protocol FOTS-ID 3886 and 7240, Mattilsynet, Norway.

\section{Publisher's Note}

Springer Nature remains neutral with regard to jurisdictional claims in published maps and institutional affiliations.

\section{Author details}

${ }^{1}$ Department of Pharmacology, Institute of Clinical Medicine, University of Oslo and Oslo University Hospital, Postboks 1057 Blindern, 0316 Oslo, Norway. ${ }^{2}$ Division of Anatomy, Institute of Basic Medical Sciences, University of Oslo, Oslo, Norway.

Received: 1 September 2016 Accepted: 7 March 2017

Published online: 21 March 2017

\section{References}

1. Painter MM, Atagi Y, Liu C-C, Rademakers R, Xu H, Fryer JD, Bu G. TREM2 in CNS homeostasis and neurodegenerative disease. Mol Neurodegener. 2015;10:43.

2. Walter J. The triggering receptor expressed on myeloid cells 2: a molecular link of neuroinflammation and neurodegenerative diseases. J Biol Chem. 2016;291:4334-41.

3. Jonsson T, Stefansson H, Steinberg S, Jonsdottir I, Jonsson PV, Snaedal J, Bjornsson S, Huttenlocher J, Levey Al, Lah JJ, Rujescu D, Hampel H, Giegling I, Andreassen OA, Engedal K, Ulstein I, Djurovic S, Ibrahim-Verbaas C, Hofman A, Ikram MA, van Duijn CM, Thorsteinsdottir U, Kong A, Stefansson K. Variant of TREM2 associated with the risk of Alzheimer's disease. N Engl J Med. 2013:368:107-16.

4. Guerreiro R, Wojtas A, Bras J, Carrasquillo M, Rogaeva E, Majounie E, Cruchaga C, Sassi C, Kauwe JSK, Younkin S, Hazrati L, Collinge J, Pocock J, Lashley T, Williams J, Lambert J-C, Amouyel P, Goate A, Rademakers R, Morgan K, Powell J, St. George-Hyslop P, Singleton A, Hardy J. TREM2 variants in Alzheimer's disease. N Engl J Med. 2013;368:117-27.

5. Pottier C, Wallon D, Rousseau S, Rovelet-Lecrux A, Richard A-C, Rollin-Sillaire A, Frebourg T, Campion D, Hannequin D. TREM2 R47H variant as a risk factor for early-onset Alzheimer's disease. J Alzheimers Dis. 2013;35:45-9.

6. Melchior B, Garcia AE, Hsiung B-K, Lo KM, Doose JM, Thrash JC, Stalder AK, Staufenbiel M, Neumann H, Carson MJ. Dual induction of TREM2 and tolerancerelated transcript, Tmem176b, in amyloid transgenic mice: implications for vaccine-based therapies for Alzheimer's disease. ASN Neuro. 2010;2, e00037.

7. Jay TR, Miller CM, Cheng PJ, Graham LC, Bemiller S, Broihier ML, Xu G, Margevicius D, Karlo JC, Sousa GL, Cotleur AC, Butovsky O, Bekris L, Staugaitis SM, Leverenz JB, Pimplikar SW, Landreth GE, Howell GR, Ransohoff RM, Lamb BT. TREM2 deficiency eliminates TREM2+ inflammatory macrophages and ameliorates pathology in Alzheimer's disease mouse models. J Exp Med. 2015;212:287-95.

8. Paloneva J, Manninen T, Christman G, Hovanes K, Mandelin J, Adolfsson R, Bianchin M, Bird T, Miranda R, Salmaggi A, Tranebjærg L, Konttinen Y, Peltonen L. Mutations in two genes encoding different subunits of a receptor signaling complex result in an identical disease phenotype. Am J Hum Genet. 2002;71:656-62. 
9. Guerreiro R, Lohmann E, Bras JM, Gibbs JR, Rohrer JD, Gurunlian N, Dursun B, Bilgic B, Hanagasi H, Gurvit H, Emre M, Singleton A, Hardy J. Using exome sequencing to reveal mutations in TREM2 presenting as a frontotemporal dementia-like syndrome wihout bone involvement. JAMA Neurol. 2013;70:78-84

10. Borroni B, Ferrari F, Galimberti D, Nacmias B, Barone C, Bagnoli S, Fenoglio C, Piaceri I, Archetti S, Bonvicini C, Gennarelli M, Turla M, Scarpini E, Sorbi S, Padovani A. Heterozygous TREM2 mutations in frontotemporal dementia. Neurobiol Aging. 2014;35:934.e7-934.e10.

11. Rayaprolu S, Mullen B, Baker M, Lynch T, Finger E, Seeley W, Hatanpaa K, Lomen-Hoerth C, Kertesz A, Bigio E, Lippa C, Josephs K, Knopman D, White C, Caselli R, Mackenzie I, Miller B, Boczarska-Jedynak M, Opala G, Krygowska-Wajs A, Barcikowska M, Younkin S, Petersen R, Ertekin-Taner N, Uitti R, Meschia J, Boylan K, Boeve B, Graff-Radford N, Wszolek Z, et al. TREM2 in neurodegeneration: evidence for association of the p.R47H variant with frontotemporal dementia and Parkinson's disease. Mol Neurodegener. 2013:8:19.

12. Cady J, Koval ED, Benitez BA, Zaidman C, Jockel-Balsarotti J, Allred P, Baloh RH, Ravits J, Simpson E, Appel SH, Pestronk A, Goate AM, Miller TM, Cruchaga C, Harms MB. TREM2 variant p.R47H as a risk factor for sporadic amyotrophic lateral sclerosis. JAMA Neurol. 2014;71:449-53.

13. Lill CM, Rengmark A, Pihlstrøm L, Fogh I, Shatunov A, Sleiman PM, Wang LS, Liu T, Lassen CF, Meissner E, Alexopoulos P, Calvo A, Chio A, Dizdar N, Faltraco F, Forsgren L, Kirchheiner J, Kurz A, Larsen JP, Liebsch M, Linder J, Morrison KE, Nissbrandt H, Otto M, Pahnke J, Partch A, Restagno G, Rujescu D, Schnack C, Shaw CE, et al. The role of TREM2 R47H as a risk factor for Alzheimer's disease, frontotemporal lobar degeneration, amyotrophic lateral sclerosis, and Parkinson's disease. Alzheimers Dement. 2015;11:407-1416.

14. Kober DL, Alexander-Brett JM, Karch CM, Cruchaga C, Colonna M, Holtzman MJ, Brett TJ. Neurodegenerative disease mutations in TREM2 reveal a functional surface and distinct loss-of-function mechanisms. Elife. 2016;5:1-24.

15. Corder EH, Saunders AM, Strittmatter WJ, Schmechel DE, Gaskell PC, Small GW, Roses AD, Haines JL, Pericak-Vance MA. Gene dose of apolipoprotein E type 4 allele and the risk of Alzheimer's disease in late onset families. Science. 1993;261:921-3.

16. Strittmatter WJ, Saunders AM, Schmechel D, Pericak-Vance M, Enghild J, Salvesen GS, Roses AD. Apolipoprotein E: high-avidity binding to betaamyloid and increased frequency of type 4 allele in late-onset familial Alzheimer disease. Proc Natl Acad Sci U S A. 1993;90:1977-81.

17. Corder EH, Saunders AM, Risch NJ, Strittmatter WJ, Schechel DE, Gaskell PC, Rimmler JB, Locke PA, Conneally PM, Schmader KE, Small GW, Roses AD, Haines JL, Pericak-Vance MA. Protective effect of apolipoprotein E type 2 allele for late onset Alzheimer disease. Nature. 1994;7:180-4.

18. Mahley RW. Central nervous system lipoproteins: ApoE and regulation of cholesterol metabolism. Arterioscler Thromb Vasc Biol. 2016;36:1305-15.

19. Namba $Y$, Tomonaga M, Kawasaki H, Otomo E, Ikeda K. Apolipoprotein E immunoreactivity in cerebral amyloid deposits and neurofibrillary tangles in Alzheimer's disease and kuru plaque amyloid in Creutzfeldt-Jakob disease. Brain Res. 1991:541:163-6.

20. Näslund J, Thyberg J, Tjernberg LO, Wernstedt C, Karlström AR, Bogdanovic N, Gandy SE, Lannfelt L, Terenius L, Nordstedt C. Characterization of stable complexes involving apolipoprotein $\mathrm{E}$ and the amyloid beta peptide in Alzheimer's disease brain. Neuron. 1995:15:219-28.

21. Evans KC, Berger EP, Cho C, Weisgraber KH, Lansbury Jr PT. Apolipoprotein $E$ is a kinetic but not a thermodynamic inhibitor of amyloid formation: implications for the pathogenesis and treatment of Alzheimer disease. Proc Natl Acad Sci. 1995;92:763-7.

22. Wood SJ, Chan W, Wetzel R. Seeding of A fibril formation is inhibited by all three isotypes of apolipoprotein E. Biochemistry. 1996;35:12623-8.

23. Wisniewski T, Castaño EM, Golabek A, Vogel T, Frangione B. Acceleration of Alzheimer's fibril formation by apolipoprotein $E$ in vitro. Am J Pathol. 1994;145:1030-5.

24. Ma J, Yee A, Brewer Jr HB, Das S, Potter H. Amyloid-associated proteins alpha1-antichymotrypsin and apolipoprotein E promote assembly of Alzheimer beta-protein into filaments. Nature. 1994;372:92-4.

25. Castaño EM, Prelli F, Wisniewski T, Golabek A, Kumar RA, Soto C, Frangione B. Fibrillogenesis in Alzheimer's disease of amyloid beta peptides and apolipoprotein E. Biochem J. 1995;306:599-604.

26. Strittmatter WJ, Weisgraber KH, Huang DY, Dong LM, Salvesen GS, PericakVance M, Schmechel D, Saunders AM, Goldgaber D, Roses AD. Binding of human apolipoprotein $\mathrm{E}$ to synthetic amyloid beta peptide: isoform-specific effects and implications for late-onset Alzheimer disease. Proc Natl Acad Sci U S A. 1993;90:8098-102.
27. Garai K, Verghese PB, Baban B, Holtzman DM, Frieden C. The binding of apolipoprotein $\mathrm{E}$ to oligomers and fibrils of amyloid- $\beta$ alters the kinetics of amyloid aggregation. Biochemistry. 2014;53:6323-31.

28. Fagan AM, Watson M, Parsadanian M, Bales KR, Paul SM, Holtzman DM. Human and murine ApoE markedly alters $A \beta$ metabolism before and after plaque formation in a mouse model of Alzheimer's disease. Neurobiol Dis. 2002;9:305-18.

29. Bales KR, Liu F, Wu S, Lin S, Koger D, DeLong C, Hansen JC, Sullivan PM, Paul SM. Human APOE isoform-dependent effects on brain beta-amyloid levels in PDAPP transgenic mice. J Neurosci. 2009;29:6771-9.

30. Kim J, Jiang H, Park S, Eltorai AEM, Stewart FR, Yoon H, Basak JM, Finn MB, Holtzman DM. Haploinsufficiency of human APOE reduces amyloid deposition in a mouse model of amyloid- $\beta$ amyloidosis. J Neurosci. 2011;31:18007-12.

31. Fryer JD. Human apolipoprotein E4 alters the amyloid-beta $40: 42$ ratio and promotes the formation of cerebral amyloid angiopathy in an amyloid precursor protein transgenic model. J Neurosci. 2005;25:2803-10.

32. Castellano JM, Kim J, Stewart FR, Jiang H, DeMattos RB, Patterson BW, Fagan AM, Morris JC, Mawuenyega KG, Cruchaga C, Goate AM, Bales KR, Paul SM, Bateman RJ, Holtzman DM. Human apoE isoforms differentially regulate brain amyloid- $\beta$ peptide clearance. Sci Transl Med. 2011;3:1-11.

33. Bales KR, Verina T, Dodel RC, Du Y, Altstiel L, Bender M, Hyslop P, Johnstone EM, Little SP, Cummins DJ, Piccardo P, Ghetti B, Paul SM. Lack of apolipoprotein E dramatically reduces amyloid-beta peptide deposition. Nat Genet. 1997;17:263-4.

34. Atagi $Y$, Liu C-C, Painter MM, Chen X-F, Verbeeck C, Zheng H, Li X, Rademakers R, Kang SS, Xu H, Younkin S, Das P, Fryer JD, Bu G. Apolipoprotein $\mathrm{E}$ is a ligand for triggering receptor expressed on myeloid cells 2 (TREM2). J Biol Chem. 2015;290:26043-50.

35. Bailey CC, DeVaux LB, Farzan M. The triggering receptor expressed on myeloid cells 2 binds apolipoprotein E. J Biol Chem. 2015;290:26033-42.

36. Yeh FL, Wang Y, Tom I, Gonzalez LC, Sheng M. TREM2 binds to apolipoproteins, including APOE and CLU/APOJ, and thereby facilitates uptake of amyloid-beta by microglia. Neuron. 2016;91:328-40.

37. Daws MR, Sullam PM, Niemi EC, Chen TT, Tchao NK, Seaman WE. Pattern recognition by TREM-2: binding of anionic ligands. J Immunol. 2003;171:594-9.

38. Chen TT, Li L, Chung D-H, Allen CDC, Torti SV, Torti FM, Cyster JG, Chen C-Y, Brodsky FM, Niemi EC, Nakamura MC, Seaman WE, Daws MR. TIM-2 is expressed on $\mathrm{B}$ cells and in liver and kidney and is a receptor for $\mathrm{H}$-ferritin endocytosis. J Exp Med. 2005;202:955-65.

39. White J, Blackman M, Bill J, Kappler J, Marrack P, Gold DP, Born W. Two better cell lines for making hybridomas expressing specific $T$ cell receptors. J Immunol. 1989;143:1822-5.

40. Sanderson S, Shastri N. LacZ inducible, antigen/MHC-specific T cell hybrids. Int Immunol. 1994;6:369-76.

41. Lanier LL, Corliss BC, Wu J, Leong C, Phillips JH. Immunoreceptor DAP12 bearing a tyrosine-based activation motif is involved in activating NK cells. Nature. 1998;391(February):703-7.

42. Humphrey MB, Daws MR, Spusta SC, Niemi EC, Torchia JA, Lanier LL, Seaman WE, Nakamura MC. TREM2, a DAP12-associated receptor, regulates osteoclast differentiation and function. J Bone Miner Res. 2006;21:237-45.

43. Hsieh CL, Koike M, Spusta SC, Niemi EC, Yenari M, Nakamura MC, Seaman WE. A role for TREM 2 ligands in the phagocytosis of apoptotic neuronal cells by microglia. J Neurochem. 2009;109:1144-56.

44. Innerarity TL, Friedlander EJ, Rall SC, Weisgraber KH, Mahley RW. The receptorbinding domain of human apolipoprotein $\mathrm{E}$ : binding of apolipoprotein $\mathrm{E}$ fragments. J Biol Chem. 1983;258:12341-7.

45. Wilson C, Wardell MR, Weisgraber KH, Mahley RW, Agard DA. Threedimensional structure of the $L D L$ receptor-binding domain of human apolipoprotein E. Science (80- ). 1991;252:1817-22.

46. Cuthbert JA, Russell DW, Lipsky PE. Regulation of low density lipoprotein receptor gene expression in human lymphocytes. J Biol Chem. 1989;264:1298-304.

47. Laskowitz DT, Thekdi a D, Thekdi SD, Han SK, Myers JK, Pizzo SV, Bennett ER. Downregulation of microglial activation by apolipoprotein $\mathrm{E}$ and apoEmimetic peptides. Exp Neurol. 2001;167:74-85.

48. Hatters DM, Peters-Libeu CA, Weisgraber KH. Apolipoprotein E structure: insights into function. Trends Biochem Sci. 2006;31:445-54.

49. Blennow $K$, Hesse C, Fredman P. Cerebrospinal fluid apolipoprotein E is reduced in Alzheimer's disease. Neuroreport. 1994;5:2534-6. 
50. Schmidt C, Becker H, Zerr I. Cerebrospinal fluid apolipoprotein E concentration and severity of cognitive impairment in patients with newly diagnosed Alzheimer's disease. Am J Alzheimers Dis Other Demen. 2014;29:54-60.

51. Cruchaga C, Kauwe JSK, Nowotny P, Bales K, Pickering EH, Mayo K, Bertelsen S, Hinrichs A, Fagan AM, Holtzman DM, Morris JC, Goate AM. Cerebrospinal fluid APOE levels: an endophenotype for genetic studies for Alzheimer's disease. Hum Mol Genet. 2012;21:4558-71.

52. Haddy N, De Bacquer D, Chemaly MM, Maurice M, Ehnholm C, Evans A, Sans S, Do Carmo Martins M, De Backer G, Siest G, Visvikis S. The importance of plasma apolipoprotein $\mathrm{E}$ concentration in addition to its common polymorphism on inter-individual variation in lipid levels: results from Apo Europe. Eur J Hum Genet. 2002;10:841-50.

53. Rasmussen KL, Tybjærg-Hansen A, Nordestgaard BG, Frikke-Schmidt R. Plasma levels of apolipoprotein $\mathrm{E}$ and risk of dementia in the general population. Ann Neurol. 2015;77:301-11.

54. Park JS, Ji IJ, An HJ, Kang MJ, Kang SW, Kim DH, Yoon SY. Disease-associated mutations of TREM2 alter the processing of N-linked oligosaccharides in the Golgi apparatus. Traffic. 2015;16:510-8.

55. Lue L-F, Schmitz CT, Serrano G, Sue LI, Beach TG, Walker DG. TREM2 protein expression changes correlate with Alzheimer's disease neurodegenerative pathologies in post-mortem temporal cortices. Brain Pathol. 2015;25:469-80.

56. Ji ZS, Fazio S, Mahley RW. Variable heparan sulfate proteoglycan binding of apolipoprotein E variants may modulate the expression of type III hyperlipoproteinemia. J Biol Chem. 1994;269:13421-8.

57. Libeu CP, Lund-Katz S, Phillips MC, Wehrli S, Hernáiz MJ, Capila I, Linhardt RJ, Raffaï RL, Newhouse YM, Zhou F, Weisgraber KH. New insights into the heparan sulfate proteoglycan-binding activity of apolipoprotein E. J Biol Chem. 2001;276:39138-44.

58. Futamura M, Dhanasekaran P, Handa T, Phillips MC, Lund-Katz S, Saito H. Two-step mechanism of binding of apolipoprotein E to heparin: implications for the kinetics of apolipoprotein E-heparan sulfate proteoglycan complex formation on cell surfaces. J Biol Chem. 2005;280:5414-22.

59. Cardin AD, Hirose N, Blankenship DT, Jackson RL, Harmony JAK, Sparrow DA, Sparrow JT. Binding of a high reactive heparin to human apolipoprotein E: identification of two heparin-binding domains. Biochem Biophys Res Commun. 1986;134:783-9.

60. Weisgraber KH, Rall SC, Mahley RW, Milne RW, Marcel YL, Sparrow JT. Human apolipoprotein E-determination of the heparin binding sites of apolipoprotein E3. J Biol Chem. 1986;261:2068-76.

61. Dong J, Peters-Libeu CA, Weisgraber KH, Segelke BW, Rupp B, Capila I, Hernáiz MJ, LeBrun LA, Linhardt RJ. Interaction of the N-terminal domain of apolipoprotein E4 with heparin. Biochemistry. 2001;40:2826-34.

62. Saito H, Dhanasekaran $P$, Nguyen D, Baldwin F, Weisgraber KH, Wehrli S, Phillips MC, Lund-Katz S. Characterization of the heparin binding sites in human apolipoprotein E. J Biol Chem. 2003;278:14782-7.

63. Yamauchi Y, Deguchi N, Takagi C, Tanaka M, Dhanasekaran P, Nakano M, Handa T, Phillips MC, Lund-Katz S, Saito H. Role of the N- and C-terminal domains in binding of apolipoprotein $\mathrm{E}$ isoforms to heparan sulfate and dermatan sulfate: a surface plasmon resonance study. Biochemistry. 2008;47:6702-10

64. Schlessinger J, Lax I, Lemmon M. Regulation of growth factor activation by proteoglycans: what is the role of the low affinity receptors? Cell. 1995;83:357-60

65. Lander AD. Proteoglycans: master regulators of molecular encounter? Matrix Biol. 1998;17:465-72.

66. Park PW, Reizes O, Bernfield M. Cell surface heparan sulfate proteoglycans: selective regulators of ligand-receptor encounters. J Biol Chem. 2000;275:29923-6.

67. Parish CR. The role of heparan sulphate in inflammation. Nat Rev Immunol. 2006;6:633-43.

68. Mahley RW, Huang Y. Atherogenic remnant lipoproteins: role for proteoglycans in trapping, transferring, and internalizing. J Clin Invest. 2007;117:94-8.

69. Snow AD, Willmer J, Kisilevsky R. Sulfated glycosaminoglycans: a common constituent of all amyloids? Lab Investig. 1987;56:120-3.

70. Snow AD, Wight TN. Proteoglycans in the pathogenesis of Alzheimer's disease and other amyloidoses. Neurobiol Aging. 1989;10:481-97.

71. Van Horssen J, Kleinnijenhuis J, Maass CN, Rensink AAM, Otte-Höller I, David G, Van den Heuvel LPWJ, Wesseling P, De Waal RMW, Verbeek MM. Accumulation of heparan sulfate proteoglycans in cerebellar senile plaques. Neurobiol Aging. 2002;23:537-45.

72. O'Callaghan P, Sandwall E, Li JP, Yu H, Ravid R, Guan ZZ, Van Kuppevelt TH, Nilsson LNG, Ingelsson M, Hyman BT, Kalimo H, Lindahl U, Lannfelt L, Zhang
X. Heparan sulfate accumulation with Abeta deposits in Alzheimer's disease and Tg2576 mice is contributed by glial cells. Brain Pathol. 2008;18:548-61.

73. Lord A, Philipson O, Klingstedt T, Westermark G, Hammarström P, Nilsson KPR, Nilsson LNG. Observations in APP bitransgenic mice suggest that diffuse and compact plaques form via independent processes in Alzheimer's disease. Am J Pathol. 2011;178:2286-98.

74. Winkler K, Scharnagl H, Tisljar U, Hoschutzky H, Friedrich I, Hoffmann MM, Huttinger M, Wieland $H$, Marz W. Competition of A amyloid peptide and apolipoprotein E for receptor-mediated endocytosis. J Lipid Res. 1999:40:447-55

75. Schmechel DE, Saunders AM, Strittmatter WJ, Crain BJ, Hulette CM, Joo SH, Pericak-Vance MA, Goldgaber D, Roses AD. Increased amyloid beta-peptide deposition in cerebral cortex as a consequence of apolipoprotein $\mathrm{E}$ genotype in late-onset Alzheimer disease. Proc Natl Acad Sci U S A. 1993:90:9649-53.

76. Deane R, Sagare A, Hamm K, Parisi M, Lane S, Finn MB, Holtzman DM, Zlokovic BV. apoE isoform-specific disruption of amyloid $\beta$ peptide clearance from mouse brain. J Clin Invest. 2008;118:4002-13.

77. Ulrich JD, Finn MB, Wang $Y$, Shen A, Mahan TE, Jiang H, Stewart FR, Piccio L, Colonna M, Holtzman DM. Altered microglial response to A $\beta$ plaques in APPPS1-21 mice heterozygous for TREM2. Mol Neurodegener. 2014;9:1-9.

78. Wang Y, Cella M, Mallinson K, Ulrich JD, Young KL, Robinette ML, Gilfillan S, Krishnan GM, Sudhakar S, Zinselmeyer BH, Holtzman DM, Cirrito JR, Colonna M. TREM2 lipid sensing sustains the microglial response in an Alzheimer's disease model. Cell. 2015;160:1-11.

79. Jay TR, Hirsch AM, Broihier ML, Miller CM, Neilson LE, Ransohoff RM, Lamb BT, Landreth GE. Disease progression-dependent effects of TREM2 deficiency in a mouse model of Alzheimer's disease. J Neurosci. 2017;37:637-47.

80. Sun Y, Wu S, Bu G, Onifade MK, Patel SN, LaDu MJ, Fagan AM, Holtzman DM. Glial fibrillary acidic protein-apolipoprotein E (apoE) transgenic mice: astrocyte-specific expression and differing biological effects of astrocytesecreted apoE3 and apoE4 lipoproteins. J Neurosci. 1998;18:3261-72.

81. Sullivan PM, Knouff C, Najib J, Reddick RL, Quarfordt SH, Maeda N. Targeted replacement of the mouse apolipoprotein E gene with the common human ApoE3 allele enhances diet-induced hypercholesterolemia and artherosclerosis. I Biol Chem. 1997;272:17972-80.

82. Prada I, Ongania GN, Buonsanti C, Panina-Bordignon P, Meldolesi J. Triggering receptor expressed in myeloid cells 2 (TREM2) trafficking in microglial cells: continuous shuttling to and from the plasma membrane regulated by cell stimulation. Neuroscience. 2006;140:1139-48.

83. Gregg RE, Zech LA, Schaefer EJ, Stark D, Wilson D, Brewer Jr HB. Abnormal in vivo metabolism of apolipoprotein E4 in humans. J Clin Invest. 1986;78(September):815-21.

84. Weisgraber $\mathrm{KH}$. Apolipoprotein E distribution among human plasma lipoproteins: role of the cysteine-arginine interchange at residue 112. J Lipid Res. 1990;31:1503-11.

85. Dong LM, Weisgraber KH. Human apolipoprotein E4 domain interaction. J Biol Chem. 1996;271:19053-7.

86. Huang Y, Liu XQ, Rall Jr SC, Mahley RW. Apolipoprotein E2 reduces the low density lipoprotein level in transgenic mice by impairing lipoprotein lipase-mediated lipolysis of triglyceride-rich lipoproteins. J Biol Chem. 1998;273:17483-90

87. Narita M, Holtzman DM, Fagan AM, LaDu MJ, Yu L, Han X, Gross RW, Bu G, Schwartz AL. Cellular catabolism of lipid poor apolipoprotein E via cell surface LDL receptor-related protein. J Biochem. 2002;132:743-9.

88. Ruiz J, Kouiavskaia D, Migliorini M, Robinson S, Saenko EL, Gorlatova N, Li D, Lawrence D, Hyman BT, Weisgraber KH, Strickland DK. The apoE isoform binding properties of the VLDL receptor reveal marked differences from LRP and the LDL receptor. J Lipid Res. 2005;46:1721-31.

89. Poliani PL, Wang Y, Fontana E, Robinette ML, Yamanishi Y, Gilfillan S, Colonna M. TREM2 sustains microglial expansion during aging and response to demyelination. J Clin Invest. 2015;125:2161-70. 